\title{
Grape juice concentrate prevents oxidative DNA damage in peripheral blood cells of rats subjected to a high-cholesterol diet
}

\author{
Odair Aguiar Jr ${ }^{1}$, Andréa Pittelli Boiago Gollücke ${ }^{2}$, Bárbara Bueno de Moraes ${ }^{1}$, Gabriela Pasquini ${ }^{1}$, \\ Rodrigo Ramos Catharino ${ }^{3}$, Maria Francesca Riccio ${ }^{3}$, Silvia Saiuli Miki Ihara ${ }^{4}$ and \\ Daniel Araki Ribeiro ${ }^{1,4 *}$ \\ ${ }^{1}$ Departamento de Biociências, Universidade Federal de São Paulo (UNIFESP), Avenida Ana Costa, 95 Vila Mathias, Santos \\ 11060-001, SP, Brazil \\ ${ }^{2}$ Hexalab and Nutrition Department, Catholic University of Santos, Santos, Brazil \\ ${ }^{3}$ Department of Clinical Pathology, School of Medical Sciences, State University of Campinas, Campinas, Brazil \\ ${ }^{4}$ Departamento de Patologia, Universidade Federal de São Paulo, São Paulo, Brazil
}

(Received 17 May 2010 - Revised 9 September 2010 - Accepted 24 September 2010)

\begin{abstract}
The goal of the present study was to investigate whether subchronic treatment with grape juice concentrate is able to protect liver and peripheral blood cells against cholesterol-induced injury in rats. The effects of the grape juice concentrate treatment on histopathological changes, immunohistochemistry for cyclo-oxygenase-2 (COX-2), and basal and oxidative DNA damage induced by $\mathrm{H}_{2} \mathrm{O}_{2}$ using a single-cell gel (comet) assay were evaluated. Male Wistar rats ( $n$ 18) were divided into three groups: group 1 - negative control; group $2-$ cholesterol at $1 \%(\mathrm{w} / \mathrm{w})$ in their diet, treated for 5 weeks; group 3 - cholesterol at $1 \%$ in their chow, treated for 5 weeks, and grape juice concentrate at $222 \mathrm{mg} / \mathrm{d}$ in their drinking-water in the final week only. The results indicated that the treatment with grape juice concentrate did not show remarkable differences regarding liver tissue in group 3 compared with group 2. However, grape juice concentrate was able to decrease oxidative DNA damage induced by $\mathrm{H}_{2} \mathrm{O}_{2}$ in peripheral blood cells, as depicted by the tail moment results. COX-2 expression in the liver did not show statistically significant differences $(P>0.05)$ between groups. Taken together, the present results suggest that the administration of subchronic grape juice concentrate prevents oxidative DNA damage in peripheral blood cells.
\end{abstract}

Key words: Cholesterol diet: Rats: Grape juice: Cyclo-oxygenase-2: Oxidative DNA damage

Recently, it has been postulated that there is an increased risk of CVD or atherosclerosis in humans with hypercholesterolaemia, independently of other blood lipid levels ${ }^{(1)}$. A reduction in the serum cholesterol level in hypercholesterolaemia is therefore desirable, and has mainly been accomplished by inhibiting cholesterol synthesis or by blocking the absorption of dietary cholesterol ${ }^{(2)}$.

Phenolic-rich foods have received increasing attention due to recent findings on their association with disease prevention $^{(3)}$. Several studies have identified dietary sources of polyphenols as being mainly fruits, fruit juices and beverages, such as wine, tea and coffee ${ }^{(4,5)}$. They are thought to contribute to the putative beneficial effects. For example, oral administration of grape flavonoids has been shown to confer antioxidant protection, inhibit platelet function, reduce thrombus formation and concentration of inflammatory biomarkers and inhibit the activation of nuclear transcription factor $\mathrm{B}^{(6-9)}$.

Accumulating evidence suggests that oxidative DNA damage plays an important role in some chronic degenerative diseases, such as chronic renal failure, hypertension and myocardial infarction ${ }^{(10-12)}$. In humans, oxidative DNA damage is also considered an important promoter of cancer ${ }^{(13)}$. It has been recognised as a major cause of cell death and mutations in all aerobic organisms. Some authors have demonstrated that red grape juice ingestion results in increased serum antioxidant capacity and protection of LDL against oxidation, and thus a non-alcoholic red grape extract may have similar beneficial effects to red wine ${ }^{(14)}$. However, to the best of our knowledge, no studies have addressed whether it also prevents the formation of single- and double-strand breaks induced by hyperlipidaemia.

Abbreviations: COX, cyclo-oxygenase; ESI, electrospray ionisation. 
Cyclo-oxygenase (COX) is the rate-limiting enzyme in the conversion of arachidonic acid to PG, which has two isoforms: COX-1 and COX-2. COX-1 is constitutively expressed in many tissues and mediates the synthesis of PG required for normal physiological function. COX-2 is normally undetectable in most of the tissues but is rapidly induced by pro-inflammatory or mitogenic stimuli ${ }^{(15)}$. Although it has been documented that grape juice polyphenols can prevent inflammation, eliminate excess free radicals and stimulate the regeneration of damaged cells or tissues ${ }^{(16)}$, no studies have revealed the role of COX-2 following the hypercholesterolaemic state treated with grape juice.

Electrospray ionisation-mass spectrometry (ESI-MS) with a direct infusion of the sample has emerged as a robust alternative for the fingerprinting characterisation of foods, with a fast and simple preparation of samples. This new technique has been successfully applied in the typification of several beverages ${ }^{(17)}$, and most recently, in grape juice $^{(18)}$. ESI-MS fingerprinting is a convenient method for the direct analysis of grape juice concentrate, as most of the molecules bearing acidic or basic sites can be detected. The MS/MS technique with collision-induced dissociation is used for a more detailed structural elucidation of compounds.

Grape juice concentrate has recently been used as an alternative natural food colourant to replace synthetic colours suspected of having certain adverse effects ${ }^{(19)}$. The product is obtained by nanofiltration of the juice from red grapes (Vitis labrusca, mostly of the Concord variety), with subsequent concentration at $68^{\circ}$ Brix by evaporation.

This results in a concentrated syrup with higher colour intensity, due to greater amounts of polyphenols. Thanks to its phenolic content, one could speculate that grape juice concentrate might exert physiological effects.

As a result, and because of limited evidence, the aim of the present study was to investigate whether grape juice concentrate can modulate the hypercholesterolaemic state in rats, by means of DNA damage and COX-2 expression.

\section{Materials and methods}

\section{Animals and experimental design}

All experimental protocols involving animals conformed to the procedures described in the Guiding Principles for the Use of Laboratory Animals. The study was approved by the Animal Committee of Federal University of São Paulo, UNIFESP, SP, Brazil.

Male Wistar rats (8 weeks old), weighing approximately $250 \mathrm{~g}$, were obtained from the Centro de Desenvolvimento de Modelos Experimentais, Federal University of São Paulo, SP, Brazil. They were maintained under controlled conditions of temperature $\left(24 \pm 2^{\circ} \mathrm{C}\right), 12 \mathrm{~h}$ light $-12 \mathrm{~h}$ dark cycles and with free access to water and commercial diet (Nuvital, Paraná, Brazil). All animals were acclimatised for $7 \mathrm{~d}$ before the experiment, fed ad libitum standard pellet chow and fresh water.

A total of eighteen rats were randomly divided into three groups (six animals per group). To induce a hypercholesterolaemic state, twelve animals were treated with a standard rat chow diet added with $1 \%(\mathrm{w} / \mathrm{w})$ cholesterol (C8503; Sigma Chemical Company, St Louis, MO, USA) and 0.25\% (w/w) cholic acid (C1254; Sigma Chemical Company; cholesterol-enriched diet), according to the methodology described by Manzoni et al. ${ }^{(20)}$. Immediately after weaning, animals were fed a cholesterol-enriched diet for 5 weeks to induce hypercholesterolaemia. Animals were divided into two groups: six animals without any treatment (positive control) and six animals receiving grape juice concentrate, freshly prepared, dissolved in their drinking-water in the final week only (in the final $7 \mathrm{~d}$ ). A total of six animals served as the negative control group. Body weight was recorded weekly.

At the end of the experimental period, the rats were killed with $0.4 \%$ sodium pentobarbital $(1 \mathrm{ml} / \mathrm{kg}$, intraperitoneally). The livers were longitudinally bisected for morphological and biochemical examinations. For this purpose, a fragment from the liver was homogenised in two volumes of $\mathrm{NaCl}$ at $0.9 \%$ to promote cell separation. Then, a volume of $20 \mu \mathrm{l}$ supernatant was subjected to a single-cell gel (comet) assay ${ }^{(21)}$. The remainder of the tissues were fixed in 10\% buffered formalin (Merck, Darmstadt, Germany), embedded in paraffin blocks and stained with haematoxylin and eosin (Merck, Whitehouse Station, NJ, USA).

\section{Grape juice concentrate intake}

Animals were given $222 \mathrm{mg} / \mathrm{d}$ of grape juice concentrate (G8000 $^{\mathrm{TM}}$; Golden Sucos, Farroupilha-RS, Brazil) in their drinking-water. The amount of polyphenols was calculated to be equivalent to four glasses $(200 \mathrm{ml}$ each) of natural grape juice $^{(22)}$ and adjusted to the fastest animal metabolism (twice as fast as humans). According to the American Dietetic Association, human consumption of approximately $200-500 \mathrm{ml}$ of grape juice presents moderate to strong evidence of positive physiological effects ${ }^{(23)}$.

\section{Determination of total phenols and in vitro antioxidant activity of grape juice concentrate}

Total phenols were measured by the Folin-Ciocalteu assay $^{(24)}$, using gallic acid (Sigma-Aldrich, St Louis, MO, USA) for the standard curve, and the results were expressed as $\mathrm{mg}$ gallic acid equivalents $/ \mathrm{kg}$. The readings (in triplicate) were taken at $740 \mathrm{~nm}$, using a Genesis 2 spectrometer. For the evaluation of in vitro antioxidant activity, the 1,1-diphenyl-2-picrylhydrazil (Sigma-Aldrich, Steinheim, Germany) assay was used based on the methods of Brand-Williams et $a l .{ }^{(25)}$, as modified by Kim et al. ${ }^{(26)}$. Absorbance was measured with a Beckman spectrometer 
at $517 \mathrm{~nm}$ before the addition of samples and after $30 \mathrm{~min}$. The difference was plotted on a vitamin C (ascorbic acid) (Merck, USA) standard curve. Analyses were carried out in triplicate and the results were expressed in $\mathrm{mg}$ vitamin $\mathrm{C}$ equivalents $/ \mathrm{kg}$.

\section{Characterisation of grape juice concentrate by electrospray ionisation-mass spectrometer fingerprinting}

ESI-MS data were collected in the negative-ion mode on an API5000 mass spectrometer (Applied Biosystems/MDS Analytical Technologies, ON, Canada). Typical ESI-MS conditions were as follows: curtain gas, ion source gas and ion transfer voltage were $10 \mathrm{~V}, 15$ and $4 \mathrm{kV}$, respectively, with a desolvation temperature of $200^{\circ} \mathrm{C}$. To each sample $(0 \cdot 1 \mathrm{ml})$, $1 \mathrm{ml}$ of a methanol-water solution $(7: 3, \mathrm{v} / \mathrm{v})$ and $0 \cdot 1 \mathrm{ml}$ of a methanol solution of ammonia $(0 \cdot 1 \%, \mathrm{v} / \mathrm{v})$ were added. The diluted solution was then directly infused into the ESI source at a flow rate of $10 \mu \mathrm{l} / \mathrm{min}$ via a microsyringe pump. The mass analyser was set to scan along a $\mathrm{m} / \mathrm{z}$ range of 50-1000. ESI-MS/MS experiments were carried out by selection of a specific ion by Q1 and then submitting this to collision-induced dissociation with $\mathrm{Ar}$ in a collision chamber. The collision energy was optimised for each component, varying from 15 to $50 \mathrm{~V}$. ESI-MS data from the sample were extracted using the Analyst 1.4.1 (Applied Biosystems/MDS Analytical Technologies). Mass spectrum data were accumulated over $60 \mathrm{~s}$. The degree of confidence for this method is $99 \%$.

\section{Measurement of cholesterol levels}

Measurements of total cholesterol were performed through specific enzymatic kits as follows: to determine total cholesterol, the fast colour method was employed with reagents from the Sera Pak-Ames-Analyzer (RAXT-Technicon, Ames, IA, USA).

\section{Histopathological analysis}

Histopathological changes, including steatosis and inflammation, were analysed by the semi-quantitative method (Table 1) according to Zhang et al. ${ }^{(27)}$.

Table 1. Score criteria for hepatopathological changes (including steatosis and inflammation) ${ }^{(26)}$

\begin{tabular}{lcl}
\hline Score & Steatosis area (\%) & Inflammation \\
\hline 0 & 0 & 0 \\
1 & $<30$ & $\begin{array}{l}\text { Watering degeneration and some } \\
\text { small necrosis } \\
\text { Ballooning degeneration, more small } \\
\text { necrosis, mallory body and } \\
\text { locally PMN infiltration } \\
\text { Severe degeneration and necrosis } \\
\text { and bridging necrosis }\end{array}$ \\
3 & $<30$ & \\
\hline
\end{tabular}

PMN, polymorphonuclear leucocyte.

\section{Single-cell gel (comet) assay and challenge assay}

The peripheral blood and liver samples collected from each animal were divided into two aliquots of $30 \mu \mathrm{l}$ each to study (1) basal DNA damage and (2) DNA damage due to oxidative stress as described elsewhere ${ }^{(21,28)}$. For this purpose, the first aliquot was immediately processed for the comet assay to assess basal DNA damage. The second aliquot was treated with a known oxidative DNA damage, $\mathrm{H}_{2} \mathrm{O}_{2}$ (Sigma-Aldrich). On the basis of previous experiments carried out in our laboratory, samples were treated with $10 \mu \mathrm{M}$-PBS (at $4^{\circ} \mathrm{C}$ for $5 \mathrm{~min}$ ). Samples were then washed three times with PBS to remove any residual mutagen and processed for the comet assay.

The protocol used for the single-cell gel (comet) assay followed the guidelines proposed by Tice et al. ${ }^{(29)}$. Briefly, a volume of $10 \mu \mathrm{l}$ peripheral blood or cellular suspensions from the liver (approximately $1 \times 10^{4}$ cells) were added to $120 \mu \mathrm{l}$ of $0.5 \%$ low-melting-point agarose at $37^{\circ} \mathrm{C}$, layered onto a pre-coated slide with $1.5 \%$ regular agarose and covered with a coverslip. After brief agarose solidification in a refrigerator, the coverslip was removed and the slides were immersed in lysis solution ( $2.5 \mathrm{M}-\mathrm{NaCl}, 100 \mathrm{~mm}$-EDTA - Merck, Darmstadt, Germany; 10 mm-Tris-HCl buffer, $\mathrm{pH}$ 10 - Sigma Aldrich; 1\% sodium sarcosinate - Sigma; with $1 \%$ Triton X-100 - Sigma; 10\% dimethyl sulphoxide Merck) for approximately $1 \mathrm{~h}$. Before electrophoresis, the slides were left in alkaline buffer $(0.3 \mathrm{~mm}-\mathrm{NaOH}$ (Merck) and $1 \mathrm{mm-EDTA}$ (Merck); $\mathrm{pH}>13$ ) for $20 \mathrm{~min}$ and electrophoresed for another $20 \mathrm{~min}$ at $25 \mathrm{~V}(0.86 \mathrm{~V} /$ $\mathrm{cm})$ and $300 \mathrm{~mA}$. After electrophoresis, the slides were neutralised in $0.4 \mathrm{M}$-Tris- $\mathrm{HCl}(\mathrm{pH} 7 \cdot 5)$, fixed in absolute ethanol and stored at room temperature until analysis. In order to minimise extraneous DNA damage from ambient UV radiation, all steps were performed with reduced illumination.

A total of fifty randomly captured comets from each slide $^{(30)}$ were blindly examined at $400 \times$ magnification, using a fluorescence microscope (Olympus, Orangeburg, NY, USA) connected through a black and white camera to an image analysis system (Comet Assay II; Perceptive Instruments, Haverhill, Suffolk, UK). This computerised image analysis system records images, computes the integrated intensity profiles for each cell, estimates the comet cell components and then evaluates the range of derived parameters. Undamaged cells have an intact nucleus without a tail and damaged cells have the appearance of a comet. To quantify the DNA damage, the tail moment was evaluated. The tail moment was calculated as the product of the tail length and the fraction of DNA in the comet tail. The comet tail moment is positively correlated with the level of DNA breakage in a cell. The mean value of the tail moment in a particular sample was taken as an index of DNA damage in such a sample. 


\section{Immunohistochemistry}

Liver sections of $3 \mu \mathrm{m}$ were deparaffinised in three changes of xylene and rehydrated in a graded series of ethanol to distilled water. For antigen retrieval, slides were placed in $0.01 \mathrm{M}$-citrate-buffer ( $\mathrm{pH}$ 6.0) and heated in a steamer for $30 \mathrm{~min}$. Endogenous peroxidases were quenched by incubating in $3 \% \mathrm{H}_{2} \mathrm{O}_{2}$ for $20 \mathrm{~min}$ at room temperature. The sections were incubated overnight at $4^{\circ} \mathrm{C}$ with a primary antibody: COX-2 mouse polyclonal antibody (1:400; Santa Cruz Biotechnology, Santa Cruz, CA, USA). Subsequently, the sections were incubated with a biotinylated secondary antibody (LSAB, Dakocytomation, Denmark) for $30 \mathrm{~min}$, washed in PBS and incubated with a streptavidin-peroxidase conjugate (LSAB) for $30 \mathrm{~min}$. Finally, the reaction was developed using 3,3'-diaminobenzidine tetrahydrochloride (Sigma) for $5 \mathrm{~min}$. The slides were briefly counterstained in haematoxylin and dehydrated, and coverslips were added. Negative and positive controls were run simultaneously. Positive controls were represented by mammary tissue. Negative controls were made by eliminating the primary antibody.

Immunostaining was scored by two trained independent observers (B. B. de M. and D. A. R.) without prior knowledge of the histopathological parameters. Discordant cases were reviewed and agreed upon before the data had been statistically analysed. For this purpose, immunohistochemically stained liver sections were analysed for the percentages of immunopositive cells in areas diagnosed as normal and in damaged liver cells. A total of 1000 liver cells were evaluated in three to five fields at $400 \times$ magnification. All values were used as labelling indices. Such a protocol was established in previous studies conducted by our research group ${ }^{(31)}$.

\section{Statistical methods}

Initial body weight, weight gain, total cholesterol and comet assay data were analysed by one-way ANOVA followed by Tukey's test. Statistical analyses for immunohistochemistry data and histopathological scores were assessed by the Kruskal-Wallis non-parametric test, followed by post hoc analysis (Dunn's test), using the SPSS software package (version 1.0; SPSS Institute, Chicago, IL, USA). A $P$ value $<0.05$ was considered statistically significant.

\section{Results}

\section{Chemical analyses}

The results of the total phenol content of grape juice concentrate showed a concentration of $45.8 \mathrm{~g}$ gallic acid equivalents/kg with an antioxidant activity of $27 \cdot 3 \mathrm{~g}$ vitamin $\mathrm{C}$ equivalents/kg. Fig. 1 displays the ESI(-)-MS spectrum of grape juice concentrate, revealing the major components of interest $(m / z 200-500)$. The ESI(-)-MS fingerprints show evidence of characteristic distributions mainly of the following compounds: dimethoxy-flavylium and disaccharide, detected as the deprotonated molecules of $m / z 313$ and 359, respectively (Table 2). Fatty acids, namely palmitic and linoleic acids, were also present in a relatively significant intensity. This technique also identified caffeoyltartaric acid, fertaric acid and caffeoylquinic acid as the main organic acids, detected as the deprotonated molecules of $m / z 311,325$ and 353, respectively.

The most abundant anthocyanidins, identified under this technique, were kaempferol-galactoside, peonidinglucoside, malvidin-glucoside, petunidin 3-O-acetylglucoside, peonidin 3-p-coumaroylglucoside and malvidin

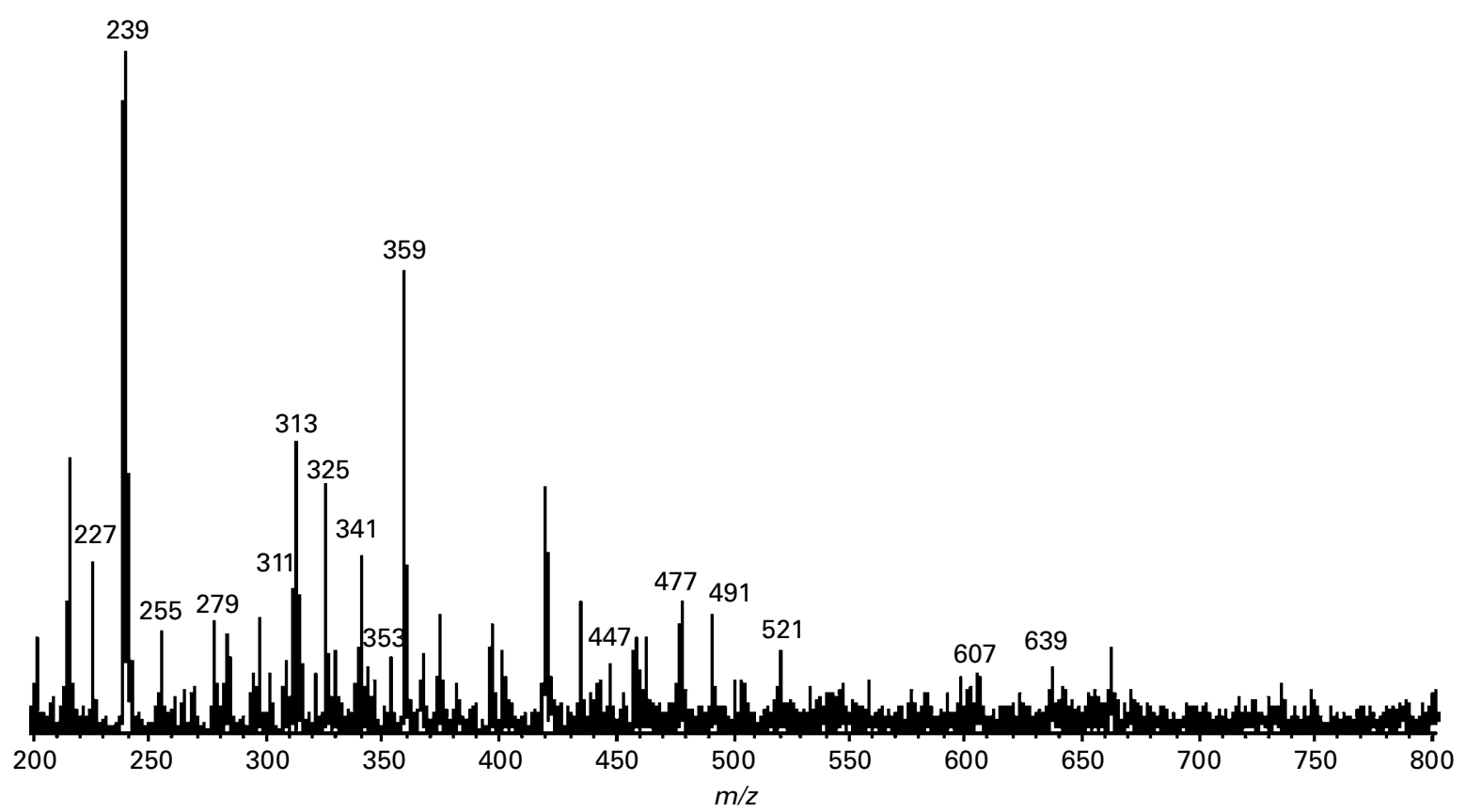

Fig. 1. Electrospray ionisation-MS fingerprinting of the grape juice concentrate. 
Table 2. Identified compounds in grape juice concentrate using electrospray ionisation-mass spectrometer/MS

\begin{tabular}{|c|c|c|c|}
\hline Compounds & $\begin{array}{l}\text { Deprotonated } \\
\text { ions } \\
{[\mathrm{M}-\mathrm{H}]^{-}(\mathrm{m} / \mathrm{z})}\end{array}$ & $\begin{array}{l}\text { MS/MS } \\
\text { ions } \\
(m / z)\end{array}$ & $\begin{array}{c}\text { Relative } \\
\text { abundances }\end{array}$ \\
\hline Resveratrol & 227 & 185 & 30 \\
\hline Palmitic acid & 255 & - & 17 \\
\hline Linoleic acid & 279 & - & 18 \\
\hline Quercetin & 301 & 151 & 10 \\
\hline Caffeoyltartaric acid & 311 & 179 & 28 \\
\hline Dimethoxy-flavylium & 313 & 295 & 50 \\
\hline Fertaric acid & 325 & 193 & 47 \\
\hline Caffeoyl glucose & 341 & 179 & 35 \\
\hline Caffeoylquinic acid & 353 & 191 & 15 \\
\hline$\left[\text { Disaccharide }+\mathrm{H}_{2} \mathrm{O}\right]^{-}$ & 359 & 162 & 65 \\
\hline Kaempferol-galactoside & 447 & 285 & 11 \\
\hline Peonidin-glucoside & 461 & 299 & 8 \\
\hline Quercetin 3-O-glucuronide & 477 & 301 & 26 \\
\hline Malvidin-glucoside & 491 & 329 & 24 \\
\hline $\begin{array}{l}\text { Petunidin } 3-O- \\
\text { acetylglucoside }\end{array}$ & 521 & 317 & 16 \\
\hline $\begin{array}{l}\text { Peonidin 3-p-coumaroyl } \\
\text { glucoside }\end{array}$ & 607 & 453 & 11 \\
\hline $\begin{array}{l}\text { Malvidin 3-O-p-coumaroyl } \\
\text { glucoside }\end{array}$ & 639 & 331 & 11 \\
\hline
\end{tabular}

3-O-p-coumaroylglucoside, presenting molecules of $\mathrm{m} / \mathrm{z}$ 461, 477, 491, 521, 607 and 639, respectively. Quercetin appeared as a single molecule and in the glucuronide form, detected as the deprotonated molecules of $\mathrm{m} / z 301$ and 477 , respectively. Resveratrol was also identified as the deprotonated molecule of $m / z 227$ in a relatively significant abundance.

\section{Clinical findings}

Neither complications nor behavioural changes were observed. The mean body weights during the experimental period are displayed in Table 3 . No statistically significant differences $(P>0.05)$ were observed in either the initial body weight or the weight gain for all groups evaluated. No animals died during the experiment.

\section{Total cholesterol levels}

Animals that received the tested combinations of cholesterol and cholic acid had significantly elevated serum cholesterol concentrations. The grape juice concentrate was not able to reduce cholesterol levels, i.e. no statistically significant differences $(P>0.05)$ were observed compared with the negative control group. These findings are shown in Table 3.

\section{Histopathological analysis}

Table 4 shows the effect of grape juice concentrate on the degree of histopathological changes in liver tissues in normal and cholesterol-induced rats. Under microscopic evaluation, liver tissues presented hepatic degeneration in the group treated with cholesterol only for 5 weeks
Table 3. Total cholesterol levels, initial and body-weight gain of rats treated with cholesterol and subjected to grape juice concentrate (GJC) therapy

(Mean values and standard deviations, $n$ 6)

\begin{tabular}{|c|c|c|c|c|c|c|}
\hline \multirow[b]{2}{*}{ Groups } & \multicolumn{2}{|c|}{$\begin{array}{l}\text { Total choles- } \\
\text { terol (ng/l) }\end{array}$} & \multicolumn{2}{|c|}{$\begin{array}{l}\text { Initial body } \\
\text { wt (g) }\end{array}$} & \multicolumn{2}{|c|}{ Wt gain } \\
\hline & Mean & SD & Mean & $\mathrm{SD}$ & Mean & SD \\
\hline $\begin{array}{l}\text { G1 (negative } \\
\text { control) }\end{array}$ & $1207^{a}$ & 135 & $329 \cdot 0$ & $30 \cdot 6$ & $80 \cdot 2$ & $15 \cdot 2$ \\
\hline $\begin{array}{l}\text { G2 (positive } \\
\text { control) }\end{array}$ & $1420^{b}$ & 120 & $333 \cdot 2$ & $29 \cdot 2$ & 74.4 & $43 \cdot 3$ \\
\hline $\begin{array}{c}\text { G3 (cholesterol } \\
\text { and GJC) }\end{array}$ & $1541^{b}$ & 200 & $319 \cdot 2$ & $24 \cdot 4$ & $62 \cdot 6$ & $25 \cdot 1$ \\
\hline
\end{tabular}

${ }^{\mathrm{a}, \mathrm{b}}$ Mean values with unlike superscript letters were significantly different $(P<0.05)$.

(Fig. 2(b)) compared with the negative control group (Fig. 2(a)). Degenerative vacuoles in hepatic tissues, increased steatosis in lobular central bands, spotty necrosis and focal necrosis with infiltration of inflammatory cells were observed in the majority of animals exposed to cholesterol only. In specimens exposed to cholesterol and grape juice concentrate, no remarkable differences were found (Fig. 2(c)).

\section{Genotoxicity data}

The single-cell gel (comet) assay was used to measure DNA damage in peripheral blood and liver cells in vivo. DNA strand breaks were represented by tail moment for fifty comets for each sample. Data were expressed as the means and standard deviations from all groups evaluated in the present experimental design. Regarding peripheral blood cells, none of the groups showed any signs of genotoxicity, as depicted by no differences in the tail moment values. These findings are summarised in Fig. 3.

Regarding liver cells, extensive DNA migration was observed in animals treated with cholesterol only compared with the negative control group. The grape juice concentrate was not able to decrease DNA migration because no statistically significant differences $(P>0.05)$ were observed between the evaluated groups (Fig. 4).

When oxidative DNA damage was evaluated, statistically significant differences were noticed among groups in peripheral blood cells. Particularly, grape juice concentrate was able to protect against oxidative DNA damage

Table 4. Total number of rats in all groups according to the degree of histopathological changes in liver tissues*

\begin{tabular}{lllll}
\hline & \multicolumn{4}{c}{ Scores } \\
\cline { 2 - 5 } Groups & 0 & 1 & 2 & 3 \\
\hline G1 (negative control) & 6 & 0 & 0 & 0 \\
G2 (positive control) & 0 & 2 & 2 & 2 \\
G3 (cholesterol and GJC) & 2 & 2 & 2 & 0 \\
\hline
\end{tabular}

GJC, grape juice concentrate.

${ }^{*}$ Mean values were not significantly different $(P>0.05)$. 

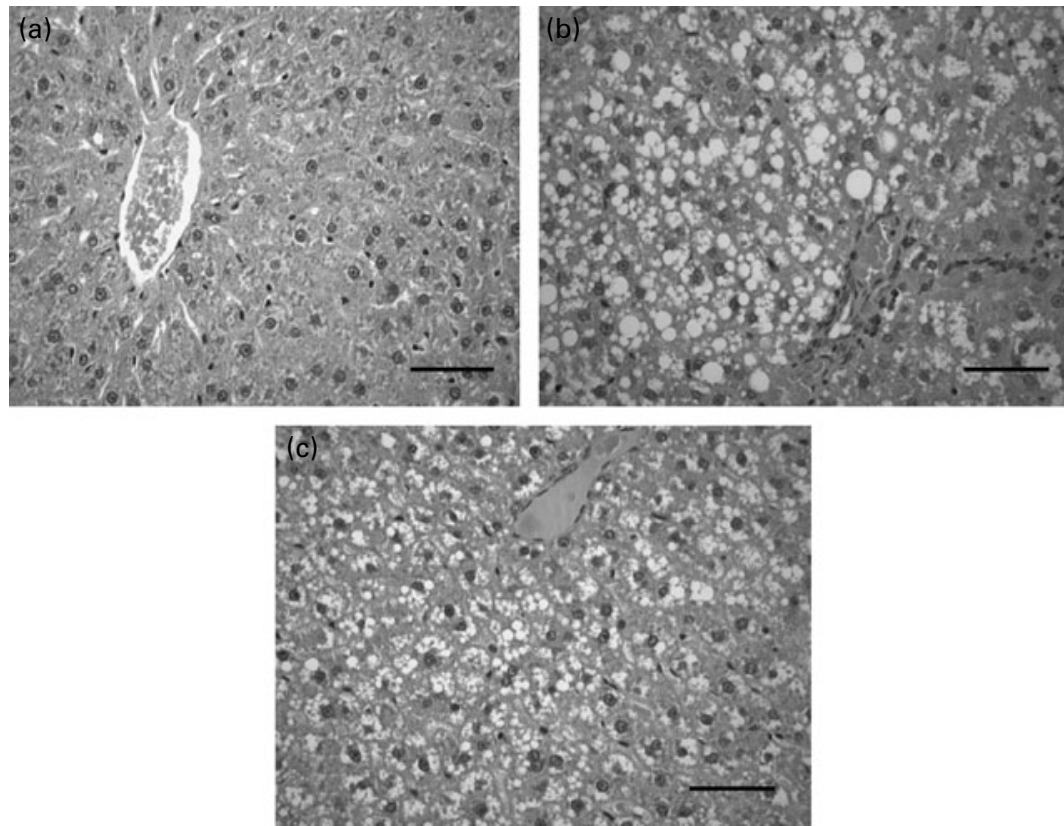

Fig. 2. Histopathological analysis of the liver tissue in rats. (a) Ordinary appearance of the liver in the control rat, (b) rats subjected to liver injury induced by cholesterol and (c) rats treated with grape juice concentrate presenting the same histopathological changes induced by cholesterol only. Haematoxylin and eosin stain; scale bar $=36 \mu \mathrm{m}$.

(Fig. 3). In animals exposed to cholesterol, high DNA damage was detected after in vitro exposure to $\mathrm{H}_{2} \mathrm{O}_{2}$ in liver cells when compared to the negative control group. Besides, no statistically significant differences $(P>0.05)$ were found in specimens treated with grape juice concentrate compared with cholesterol-induced liver DNA damage (Fig. 4).

Considering the tail moment parameter for the positive control, it was clearly observed that $\mathrm{H}_{2} \mathrm{O}_{2}$ caused higher damage in DNA in comparison with the negative control group.

\section{Immunohistochemistry}

COX-2 expression was detected in the cytoplasm of liver cells. COX-2 expression was weakly detected in all negative controls. On the whole, the expression was considered negative for the group (Fig. 5(a)). COX-2-positive cells were found in the cholesterol-treated group. The same picture appeared concerning the animals exposed to cholesterol and grape juice concentrate (Fig. 5(b)). No statistically significant differences $(P>0.05)$ were observed in the morphometric analysis between the experimental groups and the negative control group. These findings are shown in Fig. 6.

\section{Discussion}

The goal of the present study was to investigate whether subchronic treatment with grape juice concentrate can protect peripheral blood and liver cells against a highcholesterol diet in rats. The effects of the grape juice concentrate treatment on histopathological changes, oxidative DNA damage and immunohistochemistry for COX-2 were evaluated. To the best of our knowledge, such an approach has not been addressed yet.

With respect to the liver histopathological examination, cholesterol-treated rats displayed extensive steatosis, presenting liver degeneration with inflammatory cells and necrotic areas. In this regard, concomitant treatment with grape juice concentrate did not alter the pathological features induced by cholesterol, as evident from the

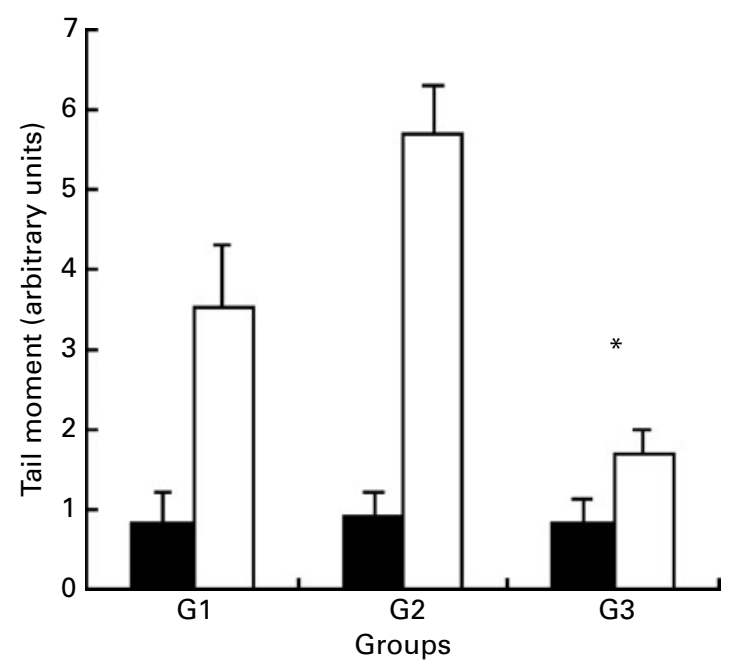

Fig. 3. DNA damage in peripheral blood cells exposed or not exposed to hydrogen peroxide. G1, negative control; G2, cholesterol-treated rats; G3, cholesterol-treated rats exposed to grape juice concentrate during 1 week. Results are expressed as the means and standard deviations. * Mean values were significantly different compared with $\mathrm{G} 1$ (positive control) $(P<0.05)$. DNA damage; $\square$, exposure to $\mathrm{H}_{2} \mathrm{O}_{2}$. 


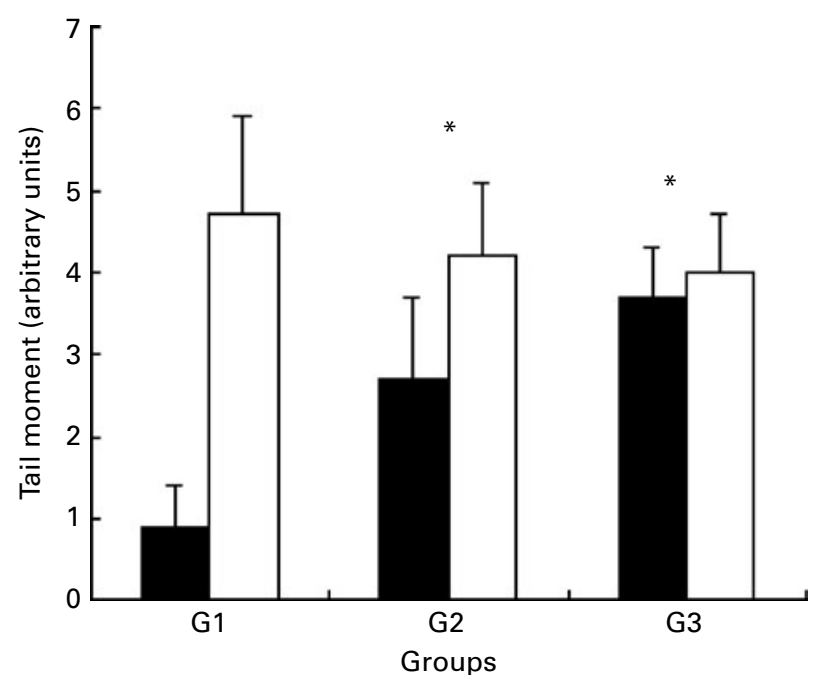

Fig. 4. DNA damage in liver cells exposed or not exposed to hydrogen peroxide. G1, negative control; G2, cholesterol-treated rats; G3, cholesteroltreated rats exposed to grape juice concentrate during 1 week. Results are expressed as the means and standard deviations. * Mean values were significantly different compared with G1 (negative control) $(P<0.05)$. $\mathbf{\square}$, DNA damage; $\square$, exposure to hydrogen peroxide.

histopathological examinations, indicating no protective effect on the liver. In addition, grape juice concentrate did not decrease cholesterol levels, because no statistically significant differences were observed between the groups. In the present study, feeding rats with $1 \%$ cholesterol and cholic acid for 5 weeks increased serum cholesterol by only $18 \%$. Probably, the amount of cholesterol was not very high compared with other studies ${ }^{(32,33)}$, but statistically significant differences were found between controls. Taken together, it seems that grape juice concentrate is not able to prevent experimental steatosis as well as hypercholesterolaemia under the experimental conditions used in the present study.

Accumulating evidence suggests that antioxidants constitute the foremost defence system that limits the toxicity associated with free radicals ${ }^{(34)}$. Hence, these antioxidants are expected to be effective against cellular injury induced by several pathological processes. Results from a few studies on animals and human subjects confirmed that polyphenolic compounds contained in grape juice exert protective effects on lymphocytes, limiting oxidative DNA damage possibly by decreasing free-radical levels ${ }^{(35,36)}$. The alkaline version of the single-cell gel (comet) assay used in the present study is sensitive to a wide variety of DNA lesions. Among them are single- and doublestrand breaks, oxidative DNA base damage, alkali-labile sites, including abasic and incomplete repair sites, and DNA-DNA/DNA-protein/DNA-drug cross-linking in any eukaryotic cell ${ }^{(29)}$. Tail moment is a virtual measure calculated by a computerised image analysis system, considering both the length of DNA migration in the comet tail and the tail intensity. Such a parameter is one of the best indices of induced DNA damage among the various parameters calculated by this method ${ }^{(29)}$. The results of the present study indicate that the alkaline single-cell gel (comet) assay, in the experimental conditions used herein, failed to detect the presence of DNA damage after the treatment with cholesterol, as well as with grape juice concentrate in peripheral blood cells. Therefore, cholesterol and grape juice concentrate are not genotoxins in such cells. However, extensive DNA damage was detected in liver cells after the treatment with cholesterol. As a result, grape juice concentrate was not able to prevent DNA damage in liver cells induced by experimental steatosis at a feasible dietary dose. These findings confirmed and extended previously published data concerning genotoxicity induced by liver steatosis ${ }^{(37)}$.

When oxidative DNA damage was induced in vitro, with reference to either peripheral blood cells or liver cells, grape juice concentrate was able to prevent oxidative DNA damage induced by $\mathrm{H}_{2} \mathrm{O}_{2}$ only in peripheral blood cells. This a result is in agreement with other studies ${ }^{(6,38)}$. Some studies have revealed antioxidant potential exerted by grape juice extracts in peripheral blood cells from haemodialysis patients and healthy subjects ${ }^{(39)}$. Moreover, recent findings have revealed antioxidant activities from organic purple grape juice in both the plasma and the liver compared with the conventional and control groups. Resveratrol is a polyphenolic compound present in significant amounts in grape juice concentrate evaluated in this setting. It has been postulated that resveratrol exhibits
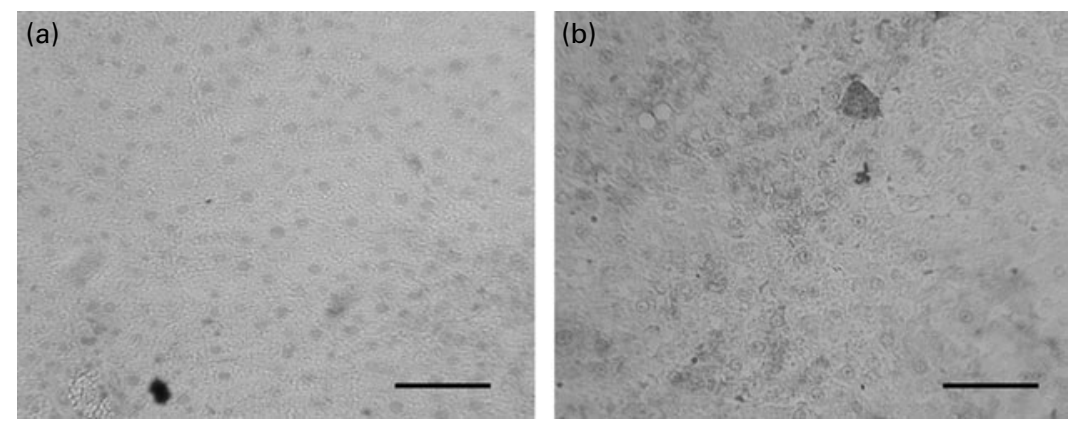

Fig. 5. Immunohistochemistry for cyclo-oxygenase-2: (a) negative control; (b) cholesterol-treated rats exposed to grape juice concentrate (immunohistochemistry stain, scale bar $=24 \mu \mathrm{m})$. 


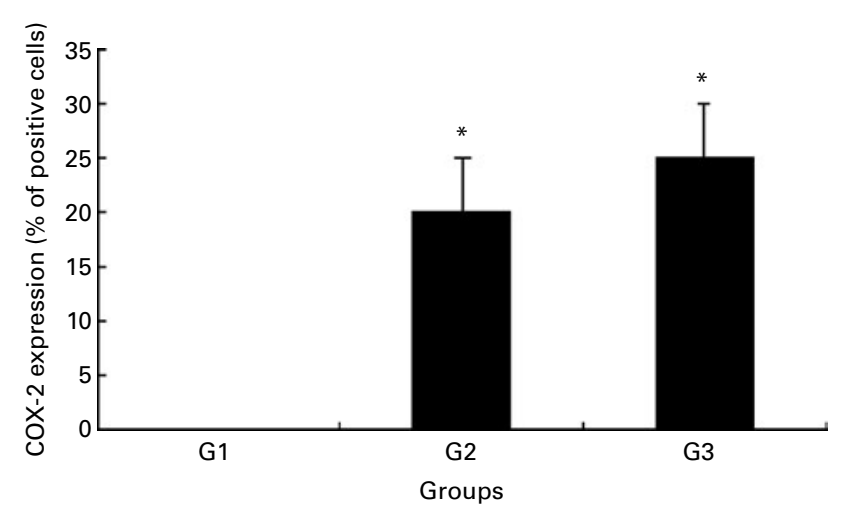

Fig. 6. Cyclo-oxygenase-2 (COX-2) labelling index. G1, negative control; G2, cholesterol-treated rats; G3, cholesterol-treated rats exposed to grape juice concentrate during 1 week. Results are expressed as the means and standard deviations. * Mean values were significantly different compared with G1 (negative control) $(P<0.05)$.

antioxidative, anti-inflammatory and chemopreventive properties in mammalian systems ${ }^{(35)}$. Conversely, Azmi et $a l .{ }^{(40)}$ have demonstrated that resveratrol also catalyses oxidative DNA degradation in vitro in the presence of transition metal ions, such as $\mathrm{Cu}^{(40)}$; this would at least partially explain the present results. Probably, the realistic grape juice concentrate dose and the short exposure were not enough to produce a positive response in the liver against oxidatively DNA-damaging agent in vitro. Moreover, limited uptake, bioefficacy or even limited bioavailability and efficacy post-metabolism in the liver may influence the positive response. Consequently, further study is required. It is important to stress that the single-cell gel (comet) assay does not necessarily predict the mutagenic potential of the test compound. One possible explanation for the absence of a close relationship to mutagenesis is that the effects seen in the single-cell gel (comet) assay for some substances mainly occur as a consequence of an error-free DNA repair process ${ }^{(41)}$. In addition, no single test is capable of detecting all genotoxic agents. Thus, for a more detailed judgement on the genotoxic potential of cholesterol as well as anti-genotoxicity exerted by grape juice concentrate, a battery of tests is necessary. Taken as a whole, we assume that grape juice concentrate can protect oxidative DNA damage in peripheral blood cells in rats.

To further elucidate putative mechanisms of action involving grape juice concentrate on rat liver injury, we designed additional experiments by means of immunohistochemistry. It has been postulated that tea polyphenols have been found to prevent inflammation, eliminate excess free radicals and stimulate the regeneration of damaged cells or tissues ${ }^{(42)}$. The present results demonstrated COX-2 expression in rats with cholesterol-damaged liver. Exposure to grape juice concentrate did not alter the COX-2 levels in liver cells, as depicted by morphometric results. Therefore, it seems that grape juice concentrate was not able to exert any anti-inflammatory activity, as depicted by COX-2 synthesis, on damaged liver cells. In fact, some studies have postulated that cholesterol exerts complex effects on the liver and that the generation of inflammatory mediators through an increased expression of COX-2 plays an important role in the pathogenesis of liver injury, such as hepatic cirrhosis ${ }^{(43)}$. By comparison, some authors have demonstrated that resveratrol, at lower doses, has few significant changes in gene expression, as depicted by complementary DNA microarrays in the rat liver ${ }^{(43)}$.

In conclusion, the results of the present study suggest that subchronic grape juice concentrate administration was able to prevent oxidative DNA damage in peripheral blood cells. Further studies, possibly with higher doses, are welcomed to advance on the subject and to elucidate the issue.

\section{Acknowledgements}

The authors are grateful to Telma E. A. do Nascimento from the Hexalab/Unisantos for her technical assistance. The present work was supported by FAPESP (Fundação de Amparo a Pesquisa do Estado de São Paulo, Grant no. 07/01228-4) and CNPq (Conselho Nacional de Desenvolvimento Científico e Tecnológico). D. A. R. is a recipient of the CNPq fellowship. All authors contributed significantly to the study design, data collection and analysis, literature review and manuscript preparation. In particular, A. P. B. G., R. R. C. and M. F. R. performed the chemical analysis of grape juice concentrate and D. A. R. performed the statistical analysis. The authors have no conflict of interest.

\section{References}

1. Lippi G, Franchini G \& Favaloro G (2010) Moderate red wine consumption and cardiovascular disease risk, beyond the 'French paradox'. Semin Thromb Hemost 36, 59-70.

2. Libby P (1995) Molecular bases of the acute coronary syndromes. Circulation 91, 2844-2850.

3. Arts IC \& Hollman PC (2005) Polyphenols and disease risk in epidemiologic studies. Am J Clin Nutr 81, 317S-325S.

4. Beecher GR (2003) Overview of dietary flavonoids, nomenclature occurrence and intake. J Nutr 133, 3248S-3254S.

5. Scalbert A, Johnson IT \& Saltmarsh M (2005) Polyphenols, antioxidants and beyond. Am J Clin Nutr 81, 215S-217S.

6. Dani C, Oliboni LS, Umezu FM, et al. (2009) Antioxidant and antigenotoxic activities of purple grape juice - organic and conventional - in adult rats. J Med Food 12, 1111-1118.

7. Nichols JA \& Katiyar SK (2001) Skin photoprotection by natural polyphenols, anti-inflammatory antioxidant and DNA repair mechanisms. Arch Dermatol Res 302, 71-83.

8. Vitseva O, Varghese S, Chakrabarti S, et al. (2005) Grape seed and skin extracts inhibit platelet function and release of reactive oxygen intermediates. J Cardiovasc Pharmacol 46, 445-451.

9. Sharma SD, Meeran SM \& Katiyar SK (2007) Dietary grape seed proanthocyanidins inhibit UVB-induced oxidative stress and activation of mitogen-activated protein kinases and nuclear factor-kappaB signaling in in vivo SKH-1 hairless mice. Mol Cancer Ther 6, 995-1005. 
10. Nishi EE, Campos RR, Bergamaschi CT, et al. (2010) Vitamin $\mathrm{C}$ prevents DNA damage induced by renovascular hypertension in multiple organs of Wistar rats. Human Exp Toxicol 29, 593-599.

11. Bruttos JB, Bergamaschi CT, Ribeiro DA, et al. (2009) Cardioprotective actions of ascorbic acid during isoproterenol-induced acute myocardial infarction in rats. Pharmacology 84, 29-37.

12. Ribeiro DA, Campos RR \& Bergamaschi CT (2009) Chronic renal failure induces genetic instability in multiple organs of Wistar rats. Eur J Clin Invest 39, 289-295.

13. Tudek B, Winczura A, Janik J, et al. (2010) Involvement of oxidatively damaged DNA and repair in cancer development and aging. Am J Transl Res 2, 254-284.

14. Day AP, Kemp HJ, Bolton C, et al. (1997) Effect of concentrated red grape juice consumption on serum antioxidant capacity and low-density lipoprotein oxidation. Ann Nutr Metab 41, 353-357.

15. Ye Y, Martinez JD, Perez-Polo RJ, et al. (2008) The role of eNOS, iNOS and NF-kappaB in upregulation and activation of cyclooxygenase- 2 and infarct size reduction by atorvastatin. Am J Physiol Heart Circ Physiol 295, H343-H351.

16. Kim M, Murakami A, Miyamoto S, et al. (2010) The modifying effects of green tea polyphenols on acute colitis and inflammation-associated colon carcinogenesis in male ICR mice. Biofactors 36, 43-51.

17. Catharino RR, Cunha IBS, Fogaça A, et al. (2006) Characterization of must and wine of six varieties of grapes by direct infusion electrospray ionization mass spectrometry. $J$ Mass Spect 41, 185-190.

18. Gollucke AP, Catharino RB, Souza JC, et al. (2009) Evolution of major phenolic components and radical scavenging activity of grape juices through concentration process and storage. Food Chem 112, 868-873.

19. Beseler L (1999) Effects on behavior and cognition, diet and artificial colors flavors and preservatives. Int Pediatr 14, $41-43$.

20. Manzoni MS, Rossi EA, Carlos IZ, et al. (2005) Fermented soy product supplemented with isoflavones affected fat depots in juvenile rats. Nutrition 21, 1018-1024.

21. Andersen ML, Ribeiro DA, Alvarenga TA, et al. (2010) Are endogenous sex hormones related to DNA damage in paradoxically sleep-deprived female rats? Horm Behav $\mathbf{5 7}$, 216-221.

22. Gollucke AP, Souza JC \& Tavares DQ (2008) + -Catechin and --epicatechin levels of concentrated and ready-todrink grape juices through storage. Int J Food Sci Technol 43, 1855-1859.

23. ADA American Dietetic Association (2004) Position of the American Dietetic Association: functional foods. $J$ Am Diet Assoc 104, 814-826.

24. Singleton VL \& Rossi JA (1965) Colorimetry of total phenolics with phosphomolybdic-phosphotungstic acid reagents. Am J Enol Vitic 16, 144-158.

25. Brand-Williams W, Cuvelier ME \& Berset C (1995) Use of free radical method to evaluate antioxidant activity. Lebensm Wissensch Technol 28, 25-30.

26. Kim D-O, Lee KW, Lee HJ, et al. (2002) Vitamin C equivalent capacity VCEAC of phenolic phytochemicals. J Agric Food Chem 50, 3713-3717.
27. Zhang XG, Xu P, Liu Q, et al. (2006) Effect of tea polyphenol on cytokine gene expression in rats with alcoholic liver disease. Hepatobiliary Pancreat Dis Int 5, 268-272.

28. Saran R, Tiwari RK, Reddy PP, et al. (2008) Risk assessment of oral cancer in patients with pre-cancerous states of the oral cavity using micronucleus test and challenge assay. Oral Oncol 44, 354-360.

29. Tice RR, Agurell E, Anderson D, et al. (2000) Single-cell gel/comet assay guidelines for in vitro and in vivo genetic toxicology testing. Environ Mol Mutagen 35, 206-221.

30. Hartmann A, Agurell E, Beevers C, et al. (2000) Recommendations for conducting the in vivo comet assay. Mutagenesis 28, 45-51.

31. Fracalossi AC, Miranda SR, Oshima CT, et al. (2010) The role of matrix metalloproteinases 2 and 9 during rat tongue carcinogenesis induced by 4-nitroquinoline 1-oxide. $\mathrm{J} \mathrm{Mol}$ Histol 41, 19-25.

32. Mandukhail SU, Aziz N \& Gilani AH (2010) Studies on antidyslipidemic effects of Morinda citrifolia (Noni) fruit, leaves and root extracts. Lipids Health Dis 9, 88.

33. Cheik NC, Rossi EA, Guerra RL, et al. (2008) Effects of a ferment soy product on the adipocyte area reduction and dyslipidemia control in hypercholesterolemic adult male rats. Lipids Health Dis 7, 50.

34. Yoggeta SK, Gnanapragasam A, Kumar SS, et al. (2006) Synergistic interactions of ferulic acid with ascorbic acid its cardioprotective role during isoproterenol induced myocardial infarction in rats. Mol Cell Biochem 283, 139-146.

35. Park YK, Park E, Kim JS, et al. (2003) Daily grape juice consumption reduces oxidative DNA damage and plasma free radical levels in healthy Koreans. Mutat Res 529, 77-86.

36. Castilla P, Echarri R, Davalos A, et al. (2006) Concentrated red grape juice exerts antioxidant hypolipidemic and antiinflammatory effects in both hemodialysis patients and healthy subjects. Am J Clin Nutr 84, 252-262.

37. Fujita N, Miyachi H, Tanaka H, et al. (2009) Iron overload is associated with hepatic oxidative damage to DNA in nonalcoholic steatohepatitis. Cancer Epidemiol Biomarkers Prev 18, 424-432.

38. Rho KA \& Kim MK (2006) Effects of different grape formulations on antioxidative capacity lipid peroxidation and oxidative DNA damage in aged rats. J Nutr Sci Vitaminol (Tokyo) 52, 33-46.

39. Castilla P, Davalos A, Teruel JL, et al. (2008) Comparative effects of dietary supplementation with red grape juice and vitamin $\mathrm{E}$ on production of superoxide by circulating neutrophil NADPH oxidase in hemodialysis patients. Am J Clin Nutr 8, 1053-1061.

40. Azmi AS, Bhat SH, Hadi SM, et al. (2005) Resveratrol-CuII induced DNA breakage in human peripheral lymphocytes, implications for anticancer properties. FEBS Lett 579, $3131-3135$

41. Speit S, Hanelt S, Helbigm R, et al. (1996) Detection of DNA effects in human cells with the comet assay and their relevance for mutagenesis. Toxicol Lett 88, 91-98.

42. Morillas-Ruiz JM, Villegas Garcia JA, Lopez FL, et al. (2006) Effects of polyphenolic antioxidants on exercise-induced oxidative stress. Clin Nutr 25, 444-453.

43. Hebbar V, Shen G, Hu R, et al. (2005) Toxicogenomics of resveratrol in rat liver. Life Sci 176, 2299-2314. 